\title{
IMPRESI TEKNIS PENUGASAN TERHADAP BEBAN TUGAS SISWA DALAM PEMBELAJARAN DARING DI MADARASAH ALIYAH NEGERI 1 NGANJUK
}

\author{
Merlin Putri Wulansari \\ Institut Agama Islam Negeri Pekalongan, Indonesia \\ merlinputri5657@gmail.com
}

\begin{abstract}
Online learning should be an effective learning to reduce the spread of Covid-19. Student assignments should be packaged with creative learning media so that students do not feel burdened. Learning integration is a solution that is applied at Madrasah Aliyah Negeri 1 Nganjuk to overcome learning that does not only focus on the teacher's task. This study uses a qualitative method with a case study approach. Data collection techniques used in this study are observation, interviews and documentation. The research is intended to find out how the technical assignment of students can affect the increase in student assignment load during online learning and determine appropriate and effective solutions in overcoming the increase in student assignment load during online learning at Madarasah Aliyah Negeri 1 Nganjuk.
\end{abstract}

Keywords: Online Learning, Learning Integration, Assignment Load

\begin{abstract}
Abstrak : Pembelajaran daring seharusnya menjadi pembelajaran yang efektif untuk menekan angka penyebaran Covid-19. Penugasan siswa seharusnya dikemas dengan media pembelajaran yang kreatif sehingga siswa tidak merasa terbebani. Integrasi belajar menjadi solusi yang diterapkan di Madarasah Aliyah Negeri 1 Nganjuk untuk mengatasi pembelajaran yang tidak hanya berfokus pada tugas-tugas dari guru. Penelitian ini menggunakan metode kualitatif dengan pendekatan studi kasus. Teknik pengumpulan data yang digunakan dalam penelitian ini, yaitu obeservasi, wawancara dan dokumentasi. Penelitian dimaksudkan untuk mengetahui bagaimana teknis penugasan siswa dapat mempengaruhi peningkatan beban penugasan siswa selama pembelajaran daring serta menentukan solusi yang tepat dan efektif dalam mengatasi peningkatan beban penugasan siswa selama pembelajaran daring di Madarasah Aliyah Negeri 1 Nganjuk.
\end{abstract}

Kata Kunci: Pembelajaran Daring, Integrasi Belajar, Beban Penugasan.

\section{PENDAHULUAN}

Pandemi Covid-19 yang sedang melanda hampir seluruh dunia tidak terkecuali Indonesia memang memberikan dampak yang besar terhadap kehidupan masyarakat terutama yang berkaitan dengan mobilitas masyarakat. Banyak kebijakankebijakan yang dilakukan pemerintah Indonesia dalam memutus rantai penularan

Islamika : Jurnal Keislaman dan Ilmu Pendidikan

Volume 3, Nomor 2, Juli 2021; 149-162

https:// ejournal.stitpn.ac.id/index.php/islamika 
pandemi Covid-19, salah satunya menerapkan kebijakan social distancing, yaitu dimana warga harus menjalankan seluruh aktivitas di rumah, seperti bekerja dari rumah, belajar dari rumah, termasuk dalam melaksanakan ibadah juga dari rumah. Masyarakat Indonesia banyak yang terdampak Covid-19, bahkan setiap hari jumlah korban yang meninggal akibat virus Covid-19 terus bertambah.

Sektor pendidikan merupakan sektor yang sangat terdampak akibat pandemi Covid-19. Pembelajaran yang biasanya dilakukan di lingkungan sekolah sekarang terpaksa harus dilakukan secara virtual atau jarak jauh. Pandemi Covid-19 memaksa pendidik dan peserta didik menggunakan platform pembelajaran seperti handphone, laptop, atau komputer untuk mendukung pembelajaran saat pandemi. Kalangan masyarakat biasa menyebut sistem pembelajaran daring dengan istilah pembelajaran online (online learning). Pembelajaran daring merupakan alternatif terbaik untuk menekan angka penyebaran Covid-19. Melalui pembelajaran daring semua guru dan siswa harus siap memasuki era baru dalam dunia pendidikan untuk membangun kreativitas dan kualitas peserta didik. Tujuan dari pelaksanaan pembelajaran daring adalah untuk memberikan pengalaman belajar yang bermakna bagi siswa, tanpa membebani siswa dengan seluruh capaian kurikulum untuk kenaikan kelas maupun kelulusan. Dalam pembelajaran daring, aplikasi sosial media tidak hanya sebagai alat pengumpulan tugas atau soal-soal saja, tetapi harus dimanfaatkan sebaik mungkin untuk kelancaran proses pembelajaran daring. ${ }^{1}$

Pembelajaran daring juga digunakan sebagai alternatif pengganti pembelajaran tatap muka banyak mengalami kendala, seperti minimnya akses internet, keterbatasan kuota internet, dan perkembangan teknologi yang kurang memadai di setiap daerah. Pemilihan platform media pembelajaran sangat menentukan keberlangsungan proses pembelajaran daring agar dapat berjalan secara optimal. Platform media pembelajaran yang menyenangkan akan menarik minat beklajar peserta didik. ${ }^{2}$ Kesehatan dan

${ }^{1}$ Albitar Septian Syarifudin, "Implementasi Pembelajaran Daring Untuk Meningkatkan Mutu Pendidikan Sebagai Dampak Diterapkannya Social Distanting”, Jurnal Pendidikan Bahasa dan Sastra Indonesia, Vol. 5, No. 1, 2020, Universitas Trunojoyo Madura, hlm. 32.

2 Baroroh Indiani, "Mengoptimalkan Proses Pembelajaran dengan Media Daring pada Masa Pandemi Covid-19", Jurnal Sipatokkong, Vol. 1, No. 3, Badan Pengembangan Sumber Daya Manusia Provinsi Sulawesi Selatan, 2020, hlm. 227. 
keslamatan peserta didik, pendidik, tenaga kependidikan, keluarga, dan masyarakat merupakan prinsip utama dalam pembelajaran daring. ${ }^{3}$

Sebagian siswa memiliki persepsi negatif terhadap pembelajaran daring. Hal ini dikarenakan banyak siswa yang kurang memahami materi yang disampaikan saat pembelajaran daring. Cara penyampaian materi yang kurang menarik dan terkesan monoton membuat pembelajaran daring kurang berjalan secara efektif. Banyak masalah yang timbul dari adanya pembelajaran daring seperti minimnya akses internet untuk mendownload materi pembelajaran, data kuota internet terbatas, penyampaian materi yang kurang maksimal dari guru membuat siswa kurang bisa memahami materi yang disampaikan. ${ }^{4}$

Pembelajaran daring mulai ditetapkan di berbagai sekolah, salah satunya di Madarasah Aliyah Negeri 1 Nganjuk. Kegiatan belajar mengajar yang biasanya dilakukan secara tatap muka terpaksa harus dilakukan secara virtual. Sistem pembelajaran daring yang diterapkan di Madarasah Aliyah Negeri 1 Nganjuk adalah menggunakan e-learning. E-learning merupakan media pembelajaran secara online yang memungkinkan tersampaikannya bahan ajar guru kepada siswa. ${ }^{5}$ Ada beberapa metode pengajaran yang dilakukan saat pembelajaran daring, seperti metode penugasan, ceramah, kuis dan diskusi antar kelompok. Sistem pembelajaran daring yang diterapkan di Madarasah Aliyah Negeri 1 Nganjuk belum dapat berjalan maksimal dalam pemberian tugas kepada siswa. Terkadang jadwal pelajaran sudah ditentukan tetapi ada beberapa guru yang memberikan penugasan tidak sesuai dengan jadwal. Ketika pembelajaran daring, baik dari pihak guru atau siswa serba susah karena banyak dari siswa yang malas untuk mengikuti kegiatan pembelajaran dan guru yang kesulitan dengan media pembelajaran yang cocok untuk siswa. Selama pembelajaran daring banyak guru yang tidak mengenal secara keseluruhan siswa yang diajar, karena selama pembelajaran daring para guru belum pernah bertemu langsung dengan siswa.

${ }^{3}$ Andri Anugrahana, "Hambatan, Solusi dan Harapan: Pembelajaran Daring Selama Pandemi Covid-19 Oleh Guru Sekolah Dasar", Jurnal Pendidikan dan Kebudayaan, Vol. 10, No. 3, Universitas Sanata Dharma, 2020, hlm. 282.

${ }^{4}$ Erlina Sulistiyawati, "Persepsi Siswa Terhadap Pembelajaran Daring pada Mata Pelajaran Bahasa Indonesia di Madarasah Aliyah Negeri 2 Surakarta”, Skripsi Program Tadris Bahasa Indonesia, IAIN Surakarta, 2020, hlm. 50.

${ }^{5}$ Shinta Kurnia Dewi, "Efektivitas E-learning Sebagai Media Pembelajaran Mata Pelajaran TIK Kelas XI di SMA Negeri 1 Depok”, Skripsi, 2011, Universitas Negeri Yogyakarta, hlm. 14. 


\section{METODE PENELITIAN}

Jenis penelitian yang digunakan adalah penelitian kualitatif dengan pendekatan studi kasus, yaitu pendekatan yang memfokuskan pada kebebasan peneliti untuk meneliti suatu kasus tertentu dengan menggunakan objek penelitian sesuai dengan kehendak peneliti guna mendapatkan suatu informasi secara mendalam dan menyeluruh. ${ }^{6}$ Pendekatan studi kasus dilakukan untuk mengenai sejauh mana pengaruh teknik penugasan terhadap peningkatan beban tugas siswa dalam pembelajaran daring. Lokasi penelitian dilakukan di Madarasah Aliyah Negeri 1 Nganjuk. Fokus penelitian ini adalah mengetahui bagaimana sistem pembelajaran daring di Madarasah Aliyah Negeri 1 Nganjuk, bagaimana teknis penugasan siswa dapat mempengaruhi beban tugas siswa selama pembelajaran daring serta menentukan solusi yang tepat dan efektif dalam mengatasi peningkatan beban tugas siswa selama pembelajaran daring di Madarasah Aliyah Negeri 1 Nganjuk.

Teknik pengumpulan data yang digunakan dalam penelitian ini, yaitu obeservasi, wawancara dan dokumentasi. Subyek yang digunakan dalam penelitian ini berjumlah 6 orang, yaitu 3 subyek seorang siswa Madarasah Aliyah Negeri 1 Nganjuk, dan 3 subyek seorang guru di Madarasah Aliyah Negeri 1 Nganjuk. Pemilihan suyek ini didasarkan pada tujuan penelitian dan hasil yang ingin dicapai dalam penelitian, oleh karena itu karakteristik subyek telah disesuaikan dengan kebutuhan dalam penelitian.

\section{HASIL DAN PEMBAHASAN}

\section{A. Sistem Pembelajaran Daring di MAN 1 Nganjuk}

Pelaksanaan pembelajaran daring secara total dimulai pada tahun 2020 di seluruh belahan dunia. Hal tersebut dipengaruhi oleh penularan virus Covid-19 yang sangat cepat menyebar. Hakikat konsep pembelajaran daring ini mengalami kebingungan, yaitu antara keefektifan atau keterpaksaan. Guru merasa bingung menggunakan media pembelajaran apa agar pembelajaran daring berjalan secara efektif sehingga guru terpaksa mengikuti media pembelajaran sesuai dengan keinginan siswa. Banyak kendala-kendala lain 207.

${ }^{6}$ Djam'an dan Aan Komariah, Metode Penelitian Kualitatif, (Bandung: Alfabeta, 2014), hlm. 
yang harus dihadapi untuk menunjang pelaksanaan pembelajaran daring seperti minimnya ketersediaan listrik, akses internet, kuota internet, dan perkembangan teknologi yang kurang memadai.

Pembelajaran daring adalah bagaimana cara pemanfaatan jaringan internet dalam proses pembelajaran. Pembelajaran daring merupakan pendidikan formal yang dilakukan pendidik dan peserta didik namun bertemu secara virtual atau tidak bertatap muka langsung sehingga memelukan teknologi informasi yang interaktif dalam proses pembelajaran. ${ }^{7}$ Pembelajaran daring sangat fleksibel karena dapat dilakukan di mana dan kapan saja, tergantung dengan ketersediaan media pendukung yang digunakan. Pada tingkat Perguruan Tinggi penerapan kebijakan pembelajaran daring tidak akan mengalami banyak kendala karena biasanya setiap Perguruan Tinggi sudah mempunyai sistem akademik berbasis online. Namun, untuk pendidikan tingkat dasar, menegah dan atas pembelajaran daring akan menjadi masalah besar karena tidak semua sekolah memiliki sistem akademik berbasis online.

Pembelajaran daring adalah program penyelenggaraan kelas belajar yang luas melalui jaringan internet dan dapat dilakukan secara masif dengan keterbatasan jumlah siswa serta dilakukan dengan sistem aplikasi berbayar. Pembelajaran daring menimbulkan dampak negataif dan positif terhadap pendidik dan peserta didik. Dalam pembelajaran daring dibutuhkan jaringan internet dengan aksesibilitas, konektivitas, fleksibilitas sehingga memunculkan interaksi pembelajaran yang aktif dan kreatif. ${ }^{8}$

Salah satu kendala yang menjadi pusat perhatian dalam pembelajaran daring adalah kendala finansial dan psikologis peserta didik. Secara fiansial, peserta didik di Indonesia memiliki keterbatasan ekonomi. Banyak peserta didik tingkat SD, SMP, SMA yang tidak mengikuti pembelajaran daring karena terkendala masalah finansial seperti tidak memiliki handphone ataupun laptop sebagai fasilitas utama pembelajaran daring. Sedangkan secara psikologis, peserta didik mengalami tekanan saat mengikuti pembelajaran

${ }^{7}$ Albert Efendi Pohan, Konsep Pembelajaran Daring Berbasis Pendekatan Ilmiah, (Purwodadi: CV. Sarnu Untung, 2020), hlm. 3.

${ }^{8}$ Sri Gusti, dkk, Belajar Mandiri: Pembelajaran Daring di Tengah Pandemi Covid-19, (Bali: Yayasan Kita Menulis, 2020), hlm. 2. 
daring. Hal tersebut dipicu karena banyaknya tugas yang diberikan oleh guru dengan sedikit pemahaman materi yang disampaikan sehingga peserta didik tidak paham secara keseluruhan materi yang diberikan. Penugasan yang banyak juga dibarengi dengan tenggang waktu yang relatif sedikit, guru terkadang juga tidak menjelaskan secara detail bagaimana teknis pengerjaan tugas tersebut.

Sebagian besar guru lebih mengesampingkan pembelajaran yang berorientasi pada proses dan lebih menekankan pembelajaran yang berorientasi pada tugas serta penilaian dalam pelaksanaan pembelajaran daring ini. Namun, dalam hal ini pendidik juga tidak bisa disalahkan begitu saja, sebagian pendidik yang bersikap seperti itu karena mereka sendiri tidak memiliki persiapan yang matang untuk menghadapi pembelajaran daring. Pendidik juga belum memiliki buku pegangan tentang bagaimana harus mengadakan pembelajaran daring ini.

Berdasarkan analisis terhadap hasil wawancara dapat diketahui bahwa selama pandemi Covid-19 seluruh sistem pembelajaran yang ada di Madarasah Aliyah Negeri 1 Nganjuk berlangsung secara daring. Seluruh siswa dianjurkan untuk menggunakan aplikasi e-learning, tapi ada juga beberapa guru yang tidak memakai e-learning, jadi siswanya mengikuti gurunya. Pembelajaran selama pandemi Covid-19 tidak bisa maksimal dalam segi penilaian. Pada dasarnya durasi dalam pembelajaran daring yang hanya 45 menit setiap mata pelajaran membuat guru tidak dapat maksimal dalam memberikan materi dan penugasan pada siswa. Siswa mau menyimak materi yang disampaikan guru dan mau mengisi absen saja itu sudah cukup. Ketika dalam proses pembelajaran saja nilai siswa kurang maksimal, maka guru akan kerepotan dalam memberikan penilaian kepada siswa. ${ }^{9}$

Pada pembelajaran daring banyak sekali perubahan, baik itu dari segi perencanaan, penerapan maupun evaluasinya. Jika sebelum pandemi Covid19 guru dituntut menggunakan media fisik, sedangkan ketika pandemi Covid19 guru dituntut untuk selalu menggunakan media non fisik. Pembelajaran

\footnotetext{
${ }^{9}$ Wawancara dengan R H, (Guru Al-Qur'an Hadist MAN 1 Nganjuk), tanggal 4 Juni 2021.
} 
daring dirasa kurang efektif oleh sebagian guru di Madarasah Aliyah Negeri 1, karena baik dari pihak guru atau siswa serba susah karena banyak dari siswa yang malas untuk mengikuti kegiatan pembelajaran dan guru yang kesulitan dengan media pembelajaran yang cocok untuk siswa. Oleh karena itu, pembelajaran sebelum pandemi dirasa lebih efektif dan mudah, karena ketika ada siswa yang belum paham dengan materi pelajaran maka guru akan menggunkan metode tanya jawab dengan siswa. ${ }^{10}$

Sistem pembelajaran daring/jarak jauh di Indonesia memang masih jauh dikatakan sistem yang sempurna, dan memang pembelajaran daring tidak bisa seefektif dengan sistem tatap muka. Banyak sekali yang harus dipersiapkan agar proses pembelajaran daring bisa berjalan dengan lancar, baik dan optimal. Sistem pembelajaran daring juga masih banyak perlu dievaluasi atau dikaji ulang agar bisa sesuai dengan harapan dan tujuan pendidikan di Indonesia. Peran pemerintah, orang tua, guru sangat dibutuhkan untuk kelancaran proses pembelajaran daring agar permasalahanpermasalahan yang timbul saat pembelajaran daring bisa teratasi dengan mudah dan baik. Pada dasarnya, tujuan dari pelaksanaan pembelajaran daring adalah untuk memberikan pengalaman belajar yang bermakna bagi siswa, tanpa membebani siswa dengan seluruh capaian kurikulum untuk kenaikan kelas maupun kelulusan. Pembelajaran daring/jarak jauh bertujuan untuk peningkatan pemahaman siswa tentang bahaya penularan virus Covid-19. Seluruh kegiatan yang berkaitan dengan penugasan pembelajaran daring bisa divariasikan sesuai kebutuhan siswa.

\section{B. Pengaruh Teknis Penugasan Terhadap Beban Tugas Siswa di MAN 1}

\section{Nganjuk}

Teknik penugasan merupakan cara atau metode yang dipakai guru terhadap siswa dalam mengimplementasikan tugas atau pemberian tugas dimana siswa harus mengerjakan tugas tersebut baik secara individu atau kelompok. Guru memberikan suatu tugas tertentu agar siswa melakukan

${ }^{10}$ Wawancara dengan R N, (Guru Bahasa Arab MAN 1 Nganjuk), tanggal 4 Juni 2021. 
kegiatan belajar, baik dilakukan di kelas, di rumah, atau tempat manapun saja asalkan tugas dapat dikerjakan dengan baik oleh siswa. ${ }^{11}$ Teknik penugasan yang diberikan guru pada siswa merupakan sebuah upaya pembelajaran siswa denga cara memberikan tugas, baik dengan teknik mengahafal, menguji atau pemeriksaan atas diri siswa yang bertujuan untuk merangsang siswa agar lenih akftif dan kreatif dalam kegiatan belajar. Namun, tugas yang diberikan kepada siswa sebaiknya mempertimbangkan beberapa aspek, seperti tujuan yang akan dicapai, jenis tugas yang sesuai dengan kemampuan siswa karena tidak semua siswa memiliki kemampuan yang sama dengan yang lainnya, guru memberikan arahan mengenai tugas yang akan diberikan serta memberikan waktu yang cukup dalam pengumpulan tugasnya.

Teknik penugasan sejatinya bertujuan agar siswa lebih aktif dan kreatif sehingga menghasilkan belajar yang lebih baik lagi dengan adanya tugas-tugas latihan yang diberikan guru. Dengan banyaknya tugas yang diberikan guru pada siswa diharapkan mampu menyadarkan siswa untuk selalu memaksimalkan kemampuannya dalam belajar. Guru juga harus selalu memberikan bimbingan atau pengawasan kepada siswa sehingga siswa dapat mengerjakan dan menyelesaikan tugas dengan baik serta siswa mampu memahami segala materi yang sudah diberikan oleh guru secara maksimal. Adapun pelaksanaan teknik penugasan (resitasi) memiliki beberapa fase, diantaranya fase pemberian tugas, fase pelaksanaan tugas dan fase pertanggung jawaban tugas.

Pemberian tugas yang dilakukan oleh guru bertujuan untuk memberikan bekal tambahan wawasan pengetahuan dan pengalaman kepada siswa. Tugas yang diberikan guru biasanya dikerjakan secara individu atau berkelompok. Materi tugas yang diberikan sebaiknya berkaitan erat dengan materi pelajaran yang sedang dipelajari, memiliki batas waktu pengerjaan yang cukup dan memiliki prosedur tugas yang jelas sehingga siswa dapat memahami materi dengan baik sesuai dengan kemampuan masing-masing

${ }^{11}$ Syaiful Bahri Djamarah dan Azwan Zain, Strategi Belajar Mengajar, (Jakarta: Renika Cipta, 2006), hlm. 85 . 
siswa. ${ }^{12}$ Jadi, pemberian tugas dengan teknik yang tepat sangat penting dalam kegiatan belajar mengajar di sekolah. Tugas memang sifatnya membebankan kepada siswa, tetapi disamping itu tugas yang bersifat edukatif dapat menjadikan siswa yang aktif dan kreatif di sekolah. Dengan pemberian tugas juga memberikan pekerjaan untuk siswa di rumah sehingga siswa lebih memahami materi yang disampaian di kelas. Tugas juga harus bervariasi agar memberikan semangat pada siswa untuk lebih giat belajar.

Pembelajaran daring menuntut siswa untuk menguasai setiap materi yang diberikan oleh guru. Guru lebih banyak memberikan tugas melalui aplikasi elektronik seperti ruang obrolan Whatsapp. Semua aplikasi yang digunakan guru dalam pembelajaran daring merupakan solusi yang efektif dalam memberikan tugas kepada siswa dengan waktu yang telah ditentukan atau disepakati bersama. Namun, dalam kenyataan di lapangan banyak siswa yang menganggap tugas-tugas yang diberikan guru menjadi beban tersendiri bagi siswa. Dampak dari fenomena banyaknya beban tugas yang diberikan guru pada siswa adalah siswa mengalami depresi sehingga berujung pada bunuh diri. Berdasarkan berita yang dilansir dari laman www.Liputan6.com (2020) bahwa Jaringan Sekolah Digital Indonesia mempersoalkan mengani keefektifan pembelajaran daring. Hal ini dipicu adanya salah satu siswi SMA yang bunuh diri karena stres/depresi dengan banyaknya tugas sekolah selama pembelajaran daring. ${ }^{13}$

Kuantitas tugas yang diberika guru dalam tenggang waktu yang sedikit menjadi salah satu beban siswa dalam menjalani pembelajaran daring di masa pandemi Covid-19. Beban tugas yang ditanggung siswa selama pembelajaran daring tidak sejalan dengan visi dan misi pemerintah dalam upaya menjaga kesehatan anak sengan cara meliburkan sementara kegiatan belajar mengajar yang semula tatap muka menjadi virtual. Dalam kenyataannya, banyak siswa yang mengalami tekanan bahkan stres dengan adanya tugas-tugas sekolah

${ }^{12}$ Jamil Suprihatiningrum, Strategi Pembelajaran, (Yogyakarta: Ar-Ruzz Media, 2013), hlm. 292.

${ }_{13}$ Yopi Makdori, Siswa Bunuh Diri Karena Tugas Daring, Belajar Jarak Jauh Dinilai Perlu Evaluasi, Diakses melalui https://m.liputan6.com/news/read/4388386/siswa-bunuh-diri-karenatugas-daring-belajar-jarak-jauh-dinilai-perlu-evaluasi pada tanggal 5 Januari 2021 pukul 20.58. 
tersebut. Banyak dari siswa yang mengeluh dengan banyak nya tugas yang terkadang tidak dibarengi dengan penjelasan materi yang jelas dari guru.

Berdasarkan data yang didapatkan melalui wawancara dapat diketahui penugasan siswa selama pembelajaran daring sangat berpengaruh terhadap beban tugas siswa. Banyak siswa yang mengeluh dengan banyaknya tugas yang diberikan guru pada siswa. Tugas yang menumpuk menjadi beban bagi siswa, karena dalam hal ini guru terkadang memberi tenggang waktu yang sangat terbatas untuk pengumpulan tugas, di sisi lain masih banyak tugas dari guru lain. Tugas yang banyak dari guru juga tidak diimbangi dengan penjelasan materi yang jelas, sehingga siswa tidak mengerti secara menyeluruh mengenai materi yang disampaikan dan juga tugas yang diberikan guru, bahkan siswa tidak mengetahui bagaimana cara mengerjakan tugas tersebut. ${ }^{14}$

Ketika pembelajaran, anak yang aktif akan semangat mengerjakan tugas, sedangkan anak yang malas tidak ada niatan sama sekali untuk mengerjakan tugas. Padahal guru sudah memberi dorongan motivasi untuk mengerjakan tugas. Banyak anak yang merasa terbebani dengan banyaknya tugas selama pandemi ini. Tetapi tugas memang harus diberikan guru agar bisa mengontrol nilai siswanya. Nilai setiap anak itu berbeda-beda, terkadang ada yang di atas dan ada yang di bawah juga. Hal ini juga menjadi beban bagi guru karena harus mengangkat nilai siswa tersebut. Tugas pada akhirnya menjadi alternatif guru untuk menambah nilai siswa.

Berdasarkan keterangan dari wawancara dengan salah satu siswa Madarasah Aliyah Negeri 1 Nganjuk (MUJ) ketika pembelajaran daring guru lebih banyak menugaskan siswa untuk membaca daripada menjelaskan materi. Kemudian setelah siswa membaca, guru akan bertanya pada siswa yang belum faham mengenai materi pelajaran. Jika tidak ada yang bertanya, maka guru akan langsung memberi tugas pada siswa. Terkadang ada juga guru yang menjelaskan materi pelajaran melalui voice note. Selain tugas membaca, guru lebih banyak memberi tugas meresume terkait materi pelajaran. Dalam satu

14 Wawancara dengan B M, (Salah Satu Siswa Jurusan Keagamaan MAN 1 Nganjuk), tanggal 23 Mei 2021. 
hari tidak hanya satu tugas meresume saja terkadang bisa sampai 2-3 mapel yang tugasnya meresume semua. ${ }^{15}$

\section{Solusi Efektif dalam Mengatasi Beban Tugas Siswa Di Man 1 Nganjuk}

Dalam sistem pembelajaran daring ini banyak guru yang kebingungan harus melakukan apa dalam menyajikan pembelajaran daring yang kreatif dan variatif sehingga memberikan tugas-tugas kepada siswa yang menurut guru itu adalah solusi terbaik dalam mencapai target kurikulum. Banyak guru lebih paham dengan kurikulum pembelajaran sebelumnya ketimbang harus adaptasi kembali dengan kurikulum yang baru sesuai dengan sistem pembelajaran daring. Pola pikir pembelajaran yang bersifat satu arah tersebut akan bertolak belakang dengan pola pikir pembelajaran daring. Interaksi antara guru dan siswa yang mulanya sudah sangat minim dalam kelas, sekarang justru hanya untuk formalitas saja. Banyak guru yang hanya memberikan tugas kepada siswanya ketimbang menjelaskan materi pelajaran dengan menggunakan sistem pembelajaran tatap muka virtual.

Solusi yang tepat agar siswa tidak terbebani dengan penugasan selama pandemi adalah dengan integrasi. Pemerintah sendiri sudah mencanangkan integrasi belajar atau kolaborasi, kerjasama dengan guru mapel lain. Salah satu guru di Madarasah Aliyah Negeri 1 Nganjuk, yaitu pada mata pelajaran AlQur'an Hadist sudah mencoba solusi tersebut. Misalnya, dalam mata pelajaran Al-Qur'an Hadist terdapat materi sabar dalam menghadapi ujian dan cobaan. Kemudian guru kolaborasi/integrasi dengan mapel biologi, yang di dalam mapel biologi terdapat materi Virus sehingga nanti dalam ujian anak cukup ujian satu kali tetapi bisa mendapatkan 2 nilai mapel sekaligus. Dengan integrasi tersebut akan meringankan beban siswa dan guru. Misal ada 10 soal ujian, maka saya membuat 5 soal dan 5 soal guru mapel biologi. Dalam hal ini komunikasi antara guru 2 mapel tersebut sangat dibutuhkan.

Solusi lain yaitu penugasan dengan menggunakan media pembelajaran Quiriz: Quiziz merupakan salah satu teknologi pendidikan yang digunakan Juni 2021.

15 Wawancara dengan M U J, (Salah Satu Siswa Jurusan IPS di MAN 1 Nganjuk), tanggal 4 
dalah pembelajaran daring, karena dengan game edukasi seperti ini akan meningkatkan keaktifan dan semangat siswa. Game edukasi quiriz juga dikemas secara menarik dengan soal-soal yang mudah dan ringan sehingga meningkatkan minat belajar siswa saat belajar di rumah. Penggunaan game yang biasanya memberikan dampak negatif untuk siswa, kini bisa di manfaatkan sebagai media pembelajaran daring di saat pandemi Covid-19. ${ }^{16}$ Namun, dalam sistem Quiziz jawaban antara guru dan siswa kan harus sama. Berbeda dalam menulisan jawaban bisa dianggap salah, maka dalam prakteknya banyak anak yang mengeluh karena jawaban mereka dengan jawaban guru tidak cocok.

Dalam menjalankan pembelajaran daring dibutuhkan aplikasi sistem pembelajaran daring sehingga pembelajaran di masa pandemi dapat berjalan dengan baik serta tujuan pendidikan dapat terlaksana. Perkembangan teknologi yang pesat memudahkan sektor pendidikan untuk melaksanakan proses pembelajaran daring. Beberapa teknologi informasi yang dapat dimanfaatkan sebagai media pembelajaran daring, seperti Whatsapp, Zoom, Instagram, Youtube, Google Classroom, Google Meet, Moodle, Google Formulir dan sebagainya. Sehingga hal ini menjadi permasalahan utama baik dari proses penyelenggaraan pembelajaran daring maupun hasil pembelajaran daring. Media pembelajaran yang sering dipakai guru di Madarasah Aliyah Negeri 1 Nganjuk selama pembelajaran daring adalah Whatsapp Group. Sedangkan pengumpulan tugasnya melalui Whatsapp secara pribadi ke guru tersebut. Pemilihan media pembelajaran memang dari awal sudah sesuai dengan keputusan bersama di kelas.

Aplikasi atau teknologi informasi merupakan alat penunjang untuk keberlangsungan pembelajaran daring di masa pandemi Covid-19. Aplikasiaplikasi pembelajaran daring merupakan salah satu solusi yang efektif untuk memudahkan guru dan siswa dalam kegiatan belajar mengajar di masa pandemi Covid-19. Aplikasi pembelajaran daring dapat diakses di mana saja

${ }^{16}$ Erlis Nurhayati, "Meningkatkan Keaktifan Siswa Dalam Pembelajaran Daring Melalui Media Game Edukasi Quiziz Pada Masa Pencegahan Penyebaran Covid-19”, Jurnal Paedagogy: Jurnal Penelitian dan Pengembangan Pendidikan, Vol. 7, No. 3, 2020, Lombok Utara, hlm. 146. hlm. 147. 
dan kapan saja, tetapi dibutuhkan jaringan internet yang stabil agar kegiatan belajar mengajar dapat berjalan dengan baik. Kegiatan belajar mengajar akan tetap berjalan efektif dan efisien walaupun di masa pandemi Covid-19. Walaupun pandemi Covid-19 mengubah banyak hal tidak terkecuali sektor pendidikan, prinsip pencapaian kompetensi tidak bisa diabaikan begitu saja. Dengan demikian, pembelajaran daring tidak hanya melulu pada tugas-tugas yang banyak, tetapi tugas-tugas tersebut dapat dikemas dengan media pembelajaran yang kreatif sehingga siswa tidak merasa terbebani dengan tugas-tugas yang diberikan guru kepada siswa. Guru harus menciptakan terobosan baru untuk memecahkan masalah yang berkaitan dengan pembelajaran daring.

\section{KESIMPULAN}

Sistem pembelajaran daring di Madarasah Aliyah Negeri 1 Nganjuk adalah menggunakan e-learning, tapi ada beberapa guru yang tidak memakai e-learning, jadi siswanya mengikuti gurunya. Media pembelajaran yang sering dipakai guru di Madarasah Aliyah Negeri 1 Nganjuk selama pembelajaran daring adalah Whatsapp Group. Sedangkan teknik pengumpulannya melalui beberapa media, seperti Google Classroom, Youtube, e-learning. Teknik penugasan yang dipraktikkan di Madarasah Aliyah Negeri 1 Nganjuk adalah guru lebih banyak menugaskan siswa untuk membaca daripada menjelaskan materi pelajaran. Selain tugas membaca, tugas meresume terkait materi pelajaran juga banyak digunakan guru Madarasah Aliyah Negeri 1 Nganjuk.

Persoalan yang terjadi di Madarasah Aliyah Negeri 1 Nganjuk adalah penugasan yang banyak tanpa dibarengi dengan penjelasan materi yang baik. Banyak dari guru-guru yang hanya menjejali siswa dengan tugas banyak, sehingga hal tersebut menjadikan pembelajaran daring kurang efektif. Namun, ada beberapa guru yang menerapkan integrasi belajar sebagai solusi yang efektif untuk mengatasi peningkatan beban tugas siswa selama pembelajaran dariing. Integrasi belajar atau kolaborasi adalah kerjasama antara guru mapel satu dengan guru mapel lainnya. Beberapa guru juga menerapkan media pembelajaran Quizir, karena dengan pembelajaran game edukasi seperti ini akan meningkatkan keaktifan dan semangat siswa. 


\section{DAFTAR PUSTAKA}

Anugrahana, Andri. 2020. Hambatan, Solusi dan Harapan: Pembelajaran Daring Selama Pandemi Covid-19 Oleh Guru Sekolah Dasar. Jurnal Pendidikan dan Kebudayaan. Vol. 10. No. 3. Universitas Sanata Dharma. hlm. 282.

Dewi,Shinta Kurnia. 2011. "Efektivitas E-learning Sebagai Media Pembelajaran Mata Pelajaran TIK Kelas XI di SMA Negeri 1 Depok". Skripsi. Universitas Negeri Yogyakarta. hlm. 14.

Gusti, Sri dkk. 2020. Belajar Mandiri: Pembelajaran Daring di Tengah Pandemi Covid-19. Bali: Yayasan Kita Menulis.

Indiani, Baroroh. 2020. "Mengoptimalkan Proses Pembelajaran dengan Media Daring pada Masa Pandemi Covid-19". Jurnal Sipatokkong. Vol. 1. No. 3. Badan Pengembangan Sumber Daya Manusia Provinsi Sulawesi Selatan. hlm. 227.

Komariah, Aan dan Djam'an. 2014. Metode Penelitian Kualitatif. Bandung: Alfabeta.

Makdori, Yopi. 2020. Siswa Bunuh Diri Karena Tugas Daring, Belajar Jarak Jauh Dinilai Perlu Evaluasi. Diakses melalui https://m.liputan6.com/news/read/4388386/siswa-bunuh-diri-karena-tugasdaring-belajar-jarak-jauh-dinilai-perlu-evaluasi pada tanggal 5 Januari 2021 pukul 20.58.

Nurhayati, Erlis. 2020. "Meningkatkan Keaktifan Siswa Dalam Pembelajaran Daring Melalui Media Game Edukasi Quiziz Pada Masa Pencegahan Penyebaran Covid-19”. Jurnal Paedagogy: Jurnal Penelitian dan Pengembangan Pendidikan. Vol. 7. No. 3. Lombok Utara. hlm. 146.

Pohan, Albert Efendi. 2020. Konsep Pembelajaran Daring Berbasis Pendekatan Ilmiah. Purwodadi: CV. Sarnu Untung.

Sulistiyawati, Erlina. 2020. "Persepsi Siswa Terhadap Pembelajaran Daring pada Mata Pelajaran Bahasa Indonesia di Madarasah Aliyah Negeri 2 Surakarta”. Skripsi Program Tadris Bahasa Indonesia. IAIN Surakarta. hlm. 50.

Suprihatiningrum, Jamil. 2013. Strategi Pembelajaran. Yogyakarta: Ar-Ruzz Media.

Syarifudin, Albitar Septian. 2020. "Implementasi Pembelajaran Daring Untuk Meningkatkan Mutu Pendidikan Sebagai Dampak Diterapkannya Social Distanting". Jurnal Pendidikan Bahasa dan Sastra Indonesia. Vol. 5. No. 1. Universitas Trunojoyo Madura. hlm. 32.

Zain, Azwan dan Syaiful Bahri Djamarah. 2006. Strategi Belajar Mengajar. Jakarta: Renika Cipta. 